\title{
MICROSCOPIC ANATOMY OF THE HUMAN VERTEBRO-BASILAR SYSTEM
}

\author{
RENATO P. CHOPARD * - GUILHERME DE ARAÚJO LUCAS * \\ ADRIANA LAUDANA*
}

\begin{abstract}
SUMMARY - Concerning the structure of connective-muscular components the authors studied the walls of the terminal segments of the vertebral arteries as well as the basilar artery, utilizing the following staining methods: Azan modified by Heideinheim, Weigert's resor- $\neg$ cin-fuchsin, and Weigert modified by van Gieson. It was established that wall of the verte-ר bro-basilar system exhibits a mixed structure, muscular and elastic, by means of which the vessels are adjusted to the specific blood circulation conditions. Thus, vertebral arteries show in the most external layer of tunica media an evident external elastic lamina. In contrast, in the basilar artery the elastic tissue is localized mainly in the tunica media, and is distributed heterogeneously. In its caudal segment the elastic fibers are situated in the most internal layer of tunica media, and in the cranial segment the elastic component is homogenously distributed in the whole of tunica media.
\end{abstract}

Anatomia microscópica do sistema, vértebro basilar no homem.

RESUMO - Os autores estudam a disposição dos componentes fibromusculare» da parede das artérias vertebrais em seus segmentos terminais e a artéria basilar, usando os seguintes métodos de coloração: Azan modificado por Heidenheim, resorcina-fucsina de Weigert e Weigert modificado por van Gieson. O sistema vértebro-basilar apresentou em sua parede estrutura mista, muscular e elástica, pela qual os vasos se adaptam às condições circulatórias especificas daquela região. Besta forma, ias artérias vertebrais apresentam na camada mais externa da túnica média uma lâmina elástica limitante externa evidente, ao contrário do encontrado na artéria basilar. Neste vaso, o tecido elástico se encontra principalmente na camada média, distribuindo-se de maneira heterogênea nos segmentos estudados, ou seja, no segmento caudal as fibras elásticas se dispõem predominantemente na camada mais interna da túnica média e, no segmento cranial, o componente elástico se dispõe homogeneamente em toda a camada média.

The junction of vertebral arteries and the basilar artery produces significant hemodynamics features in the circulatory mechanism to conduct the blood up to the brain. Thus, fibrous elements arrangements of these arteries take a share in the specific circulatory conditions from that region. However, studies on the structure of the wall of vertebral arteries in their final segments and of the basilar artery are few and discordant. Argaud*, one of the first authors who studied the structure of the vertebral artery, asserted that the tunica media is mainly formed by transversal muscular fibers interposed by some thin elastic fibers. Dubreuil and Lacoste 3 studying the histophysiology of the arteries observed that the vertebral artery has a muscular structure. Stohr ${ }^{\wedge}$ studying the cerebral arteries observed that the internal elastic lamina is quite developed but there are few elastic fibers in the tunica media. Furthermore, these authors observed that the tunica adventitia is not much developed. Schumacher-Marienfrid 8 and Maximow and Bloom 5 considered the same arteries are

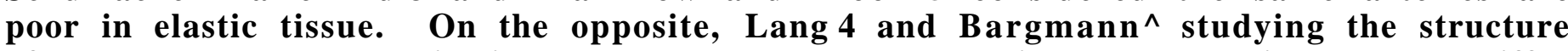
of the vertebral artery in its several segments classed it as an elastic artery. Piffer and Zorzetto 6 described the structure of the same artery and classed it as a muscular one. Concerning to the basilar artery, Roveri and coworkeres? studying the wall

* Department of Anatomy, Biomedical Science Institute, São Paulo University.

Dr. Renato Paulo Chopard - Departamento de Anatomia, Instituto de Ciências Biomédicas, Universidade de São Paulo - Av. Doutor Arnaldo 455 - 01246 São Paulo SP - Brasil. 
of this vessel classed it as being of muscular kind. Recently, Weiss and GreepiO reported that the elastic component is well developed in cerebral arteries. undertaken.

In order to contribute for clarifying this subject the present study was

\author{
MATERIALS AND METHODS
}

The anatomical material used was removed from ten cadavers with age ranging from 18 to 30 years, during necropsies performed at the Department of Pathological Anatomy of São Paulo University Medical School. That material included the terminal segment of both vertebral arteries and the basilar artery. Afterwards the specimens were fixed in a $10 \%$ formaldehyde solution, reduced in segments of 1.0 centimeter approximately, in order to make possible the comparison of parts of the system. Thus, five fragments were obtained: terminal portion of the right and left vertebral arteries; caudal medial and cranial portion of the basilar artery. These fragments were embedded in paraffin to be crosswise sectioned in series $\left(20^{\wedge} \mathrm{m}\right.$ thick $)$.

The sections were alternately stained by: the Azan method according to Heidenheim for collagenous and muscular fibers; Weigert's resorein-fuchsin method to elastic fibers; and Weigert's method (according to van Gieson to evidence elastic, collagenous and muscular fibers simultaneously. All slices obtained were examined by transillumination with microscope equipped with X10 ocular and X2.5, X6.3 and X16 objectives, and photographed in a Zeiss stereomicroscope supplied with a C35-Zeiss Photocamera,

\title{
RESULTS
}

The structure and the disposition of the connective-muscular component will be described according to the segments obtained from the vessels.

(A) Vertebral artery: terminal segment.

In this portion, the wall of the vertebral artery is formed by a thick tunica intima which exhibits a network of elastic fibers circularly disposed. In its deepest layer, the elastic fibers are condensed to form the internal elastic lamina which is evident, continual, unfold and sinuous.

The tunica media is formed by bundles of smooth muscle fibers, most of them being circularly disposed in relation to the vascular lumen. In some portions of the vascular wall the fascicles of muscular fibers are lenghtwise and obliquely oriented. These fascicles are interposed by sinuous thin elastic fibers which accompany the circular course of the muscular tissue, hence they are classed as interfascicular network. The elastic bundles are more numerous proximal to the internal layer of the above mentioned tunica. In this layer, the collagenous component is scanty and exhibits its bundles interposed between muscular fibers.

The tunica adventitia is composed by collagenous fibers network circularly disposed in relation to the vascular lumen and the elastic fibers show the same arrangement. In this region, some elastic fiber networks are closely packed forming the external elastic lamina (Fig. 1).

(B) Basilar artery: caudal, medial and cranial segments.

The wall of the basilar artery is composed by a thick tunica intima formed by elastic fibers arranged in a subendothelial elastic network of long meshes circularly oriented in relation to the vascular lumen. The internal elastic lamina is evident, thin, continual and unfold.

The tunica media is formed by fascicles of smooth muscle fibers disposed circularly, These fascicles are interposed by collagenic network and by elastic fibers disposed heterogeneously in the three studied segments of the basilar artery. Thus, in the caudal and cranial segments there is an unlikeness in the distribution of the elastic component. In the caudal portion elastic fiber networks are more numerous in the most internal layer of the tunica media and so there are few elastic fibers in the most external layer of this tunica. In the cranial portion, the elastic component is distributed with homogeneity in the whole of the tunica media. The medial segment of the basilar artery turns up as a transition region (Fig. 2, 3 and 4).

The tunica adventitia is composed by fascicles of collagenic fibers disposed circularly in the most internal layer. We still note the presence of fibers lenghtwise oriented and 

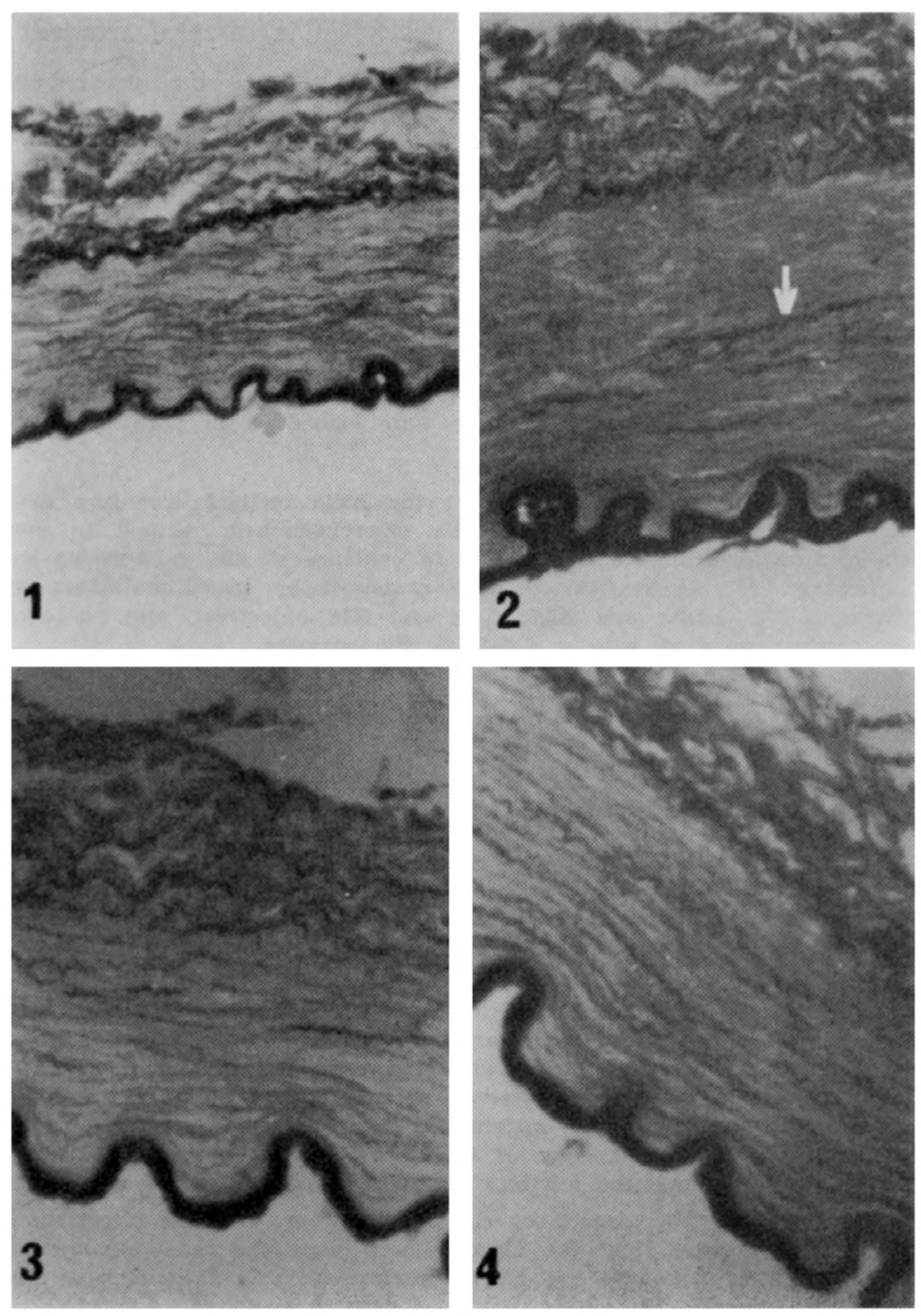

Fig. 1 - Photomicrography of the wall of the vertebral artery in its terminal segment. Thu tunica adventitia is composed by collagenous fibers network circularly disposed, in this region some elastic fibers networks are closely packed forming the external elastic lamina. The smooth muscle fibers in the tunica media are disposed circularly and are interposed by thin elastic fibers. In the tunica intima, the deepest layer is formed by elastic fibers to form the internal elastic lamina. By Weigert's resorcin-fucsin method; $\times 31$.

Fig. 2 - Photomicrography of the wall of the basilar artery-caudal segment. The tunica adventitia is composed by collagenous fibers network circularly disposed and the external elastic lamina is little evident. Observe the elastic fibers networks are more numerous in the most internal layer of the tunica media (arrow). By Weigert's resorcin-fucsin according to van Gieson; $\times 78$.

Fig. 3 - Photomicrography of the wall of the basilar artery in its medial segment showing fero elastic fibers in the tunica media. By Weigert's resorcin-fucsin according to van Gieson; $\times 78$.

Fig. 4 - Photomicrography of the wall of the basilar artery-cranial segment. The elastic component is distributed homogeneously in the whole of the tunica media. By Weigert's resorcin-fucsin according to van Gieson; $\times 78$. 
others having an oblique direction in the most external layer of the above mentioned tunica. At this level, the elastic fibers are compact and distributed homogeneously in the three segments of the basilar artery. The external elastic lamina evidence is little, and from It some fibers are directed to the tunica media,

\section{COMMENTS}

Lang 4 described the wall of the vertebral artery in its terminal segments as having an elastic structure, although he showed through diagram an increase in smooth muscular fibers in the tunica media. Bargmann2 also described that the vertebral artery has am elastic structure. Other authors such as Argaud* and Dubreuil and Lacoste3 described that the wall of the vertebral artery has a muscular structure.

The structure and the orientation of the fibrous components in the vertebral artery - in its terminal segment - showed that the tunica intima of this artery is formed by a subendothelial elastic network, and find an evident internal elastic lamina separating the tunica intima and the tunica media as did Stohr9. The tunica media is formed by fascicles of smooth muscle fibers which are circularly disposed and interposed by collagenous and elastic fibers with the same direction of the muscular fibers. At this level, the elastic bundles are more numerous proximal to the internal layer. This structure of the tunica media makes possible the regulation of the caliber of the vessel and the elastic tissue disposition is due to the hemodynamic complexity that settles down in the vertebro-basilar system. The tunica adventitia is formed by collagenous fibers network with circular disposition in the most external layer of this tunica; there are some fibers with oblique direction in the transition with the tunica media. We are in disagreement with Piffer and ZorzettoS that described an opposite arrangement to the collagenous component in this region. Schumacher-Marienfried 8 and Maximow and Bloom 5 reported that vertebral arteries have few elastic tissue. The elastic component is well distributed in the tunica adventitia in both external and internal elastic lamina. In the most internal portion of the tunica media and in the tunica intima, as it was observed in this study contradicting all those authors' conclusions.

Roveri and cowockers? asserted the wall of the basilar artery has a muscular structure although Weiss and Greep io regard the elastic component well developed in the intracranial arteries. Exuberant muscular network was found in the tunica media circularly disposed and interposed by collagenous and elastic fibers. The elastic component heterogenous arrangement suggests diferent hemodynamics conditions in the caudal and cranial extremities of the basilar artery.

Concerning the findings made in this study, the structure and the orientation of the tissue components of the walls of the vertebral and basilar arteries showed that the vessels adapt to the special circulatory conditions and that this occurs due to their lengthenings, their shortenings and their caliber variations to conduct the arterial blood up to the brain. Thus, we consider not solely the basilar artery but all vertebro-basilar system has a mixed structure, muscular and elastic.

Acknowledgements - We thank Mr. Elliot Martins Arruda for this editorial assistance* and Ms. Maria Nívia Fuzetti for her secretarial assistance.

\section{REFERENCES}

1. Argaud P. Recherches sur l'histotopographie des éléments contractiles et conjonctifs des parois artérielles chez les mollusques et les vertébrés. Phys Norm Pathol (Paris) 1900, 45:65-96.

2. Bargmann W. Histologia e Anatomia Microscópica Humanas. Ed 3. Barcelona: Labor, 1968, p 295-303.

3. Dubreuil 6, Lacoste A. Histopyshiologie des parois vasculaires artérielles et veineuses de l'homme. Ann Anat Path (Paris) 1931, $8: 988-1041$.

4. Lang J. Mikroskopische Anatomie der Arterien. Angiologie (Basel) 1965, 2 : $225-284$.

5. Maximow AA, Bloom W. Tratado de Histologia. Ed 5. Buenos Aires: Labor, 1952 , p 230.

6. Piffer CR, Zorzetto NL. Microscopic anatomy of the vertebral artery in the suboccipital and intracranial segments. Anat Anz (Jena) 1980, 147 : 382-388.

7. Roveri N, Bigi A, Dalla Serra A, Incerti A, Re G. Proprietá meccaniche dell'arteria basilare umana. Boll Soc It Biol Sper 1980, 56 : 960-964.

8. Schumacher-Marienfrid S. Compendio de Histologia Humana. Barcelona: Labor, 1948, p 95.

9. Stöhr P. Tratado de Histologia. Ed 24. Barcelona: Salvat, 1943, pg 267.

10. Weiss L, Greep RO. Hitologia. Ed 4. Rio de Janeiro: Guanabara Koogan, 1981 , p 326. 